\title{
Successful Amplification of Mitochondrial DNA from Dentin of the Bottlenose Dolphin Tursiops truncatus
}

\author{
Laura Isabel Weber ${ }^{1 *}$, Michelle Jaccottet de Luca ${ }^{1}$, André Silva Barreto ${ }^{2}$ and Tiago \\ Tolentino de Souza ${ }^{1}$ \\ ${ }^{1}$ Laboratório de Bioquímica e Biologia Molecular; ${ }^{2}$ Laboratório de Oceanografia Biológica; CTTMar, Universidade \\ do Vale do Itajaí; liweber@ univali.br; Rua Uruguai 458; Bloco 20; Sala 212; 88302-202; Itajaí - SC - Brasil
}

\begin{abstract}
Twenty-four teeth of Tursiops truncatus from the collection of the Marine Mammals Laboratory (FURG-RS) were analysed for their potential as DNA source for population genetic and taxonomic studies. All teeth were submitted to decontamination, grinding and demineralisation processes. Dentin powder was weighed for DNA extraction, which was evaluated by the amplification of two mitochondrial genes through PCR using universal primers. Cytochrome-b gene was amplified successfully. PCR products showed concentrations of 3-12 ng/ $\mu$ l for dentin powder, which was positively correlated to the quantity of dentin powder used for DNA extraction. To rule out contamination a SSCP was carried out including positive controls, and samples of humans involved in the analysis. The SSCP patterns for T. truncatus differed from all others, showing also polymorphism for the region. It was concluded that dentin was a good source of mtDNA for genetic studies in dolphins.
\end{abstract}

Key words: Dolphins, Tursiops, museum specimens, dentin, mitochondrial DNA, Cytochrome-b

\section{INTRODUCTION}

Marine mammals are usually very difficult to study because of their great mobility and inaccessibility, making difficult their observation and catching for collecting samples. This situation increases the need to search for new sources of tissues, which will allow extending molecular genetics studies. Molecular tools are excellent for understanding population genetic structure and division, for giving an idea of gene flow, migration between wider oceanographical areas, and potential barriers to gene flow (Amos, 1997). Knowing the geographical patterns of populations it will be possible to make inferences about the origin of individuals, migration routes, demographic processes and to estimate the probability of persistence of populations or of whole species (Palumbi et al., 1991).

Taxonomic studies in cetaceans are scarce compared to terrestrial mammals, and even widely known species such as the bottlenose dolphin, genus Tursiops Gervais, 1855 (Cetacea, Delphinidae), are still focus of discussion. This genus has been the subject of a long period of taxonomic confusion and uncertainty due to its great morphological variation along its wide geographical distribution, which gave rise to the description of many subspecies and species (Wang et al., 1999a,b). Tursiops truncatus (Montagu, 1821) was originally described for the North Atlantic Ocean. Other species, such as T. gillii (Dall, 1873) and T. nииапu Andrews, 1911, were described for the East Pacific Ocean; and $T$.

\footnotetext{
${ }^{*}$ Author for correspondence
} 
gephyreus Lahille, 1908, for the Southwestern Atlantic. Nowadays, all of them are considered synonyms of $T$. truncatus. The only species still accepted as a different species is T. aduncus (Ehrenberg, 1832), which showed morphological and genetic characters that allowed it to be distinguished from T. truncatus (Rice, 1998; Wang et al., 1999a,b; Reeves et al., 2004).

T. truncatus is cosmopolitan, but shows great morphological variation along its wide range of distribution (Rice, 1998). It is one of the most world-wide known marine mammal species due to its adaptation to oceanaria (Leatherwood and Reeves, 1983). It exhibits a broad range of sizes, from 2.2 to $3.8 \mathrm{~m}$ in males and 2.4 to $3.7 \mathrm{~m}$ in females with weights varying from 260 to $500 \mathrm{~kg}$ (Pinedo et al.,1992; Reeves et al., 2004). In the South-west Atlantic, this species is common in bays and coastal waters of central and south Brazil and Argentina, using also estuaries and rivers (Pinedo et al., 1992).

Few works have dealt with cetacean population in Brazilian coasts. There are comparisons of franciscana (Pontoporia blainvillei) populations from Rio de Janeiro and Rio Grande do Sul (Secchi et al., 1998); and for the bottlenose dolphin Tursiops truncatus populations from the southern region of Brazil (Barreto, 2000). Two subspecies of $T$. truncatus were identified by the last author along the Atlantic coast of South America by means of morphological dimensions of the skull, and there are enough evidence for raising these subspecies to the species level (Miranda and Barreto, 2002; Barreto, 2004).

As mentioned previously, obtaining samples from marine mammals for genetic analysis is a hard task, but has been partially solved by the use of biopsy darts (Amos, 1997). Nonetheless, this procedure requires previous knowledge of the localisation of groups and for some mammals, this type of collection is not always possible or available. Therefore, in these cases, samples must be obtained from dead animals, either from stranding or from incidental captures. Other sources of samples are preserved parts of the body, such as those stored in museums and personal collections. Nonetheless, much of this material has been treated with chemical agents that may degrade the DNA or even interfere in DNA amplification by PCR. Therefore, the present work aimed to study the potential of teeth samples of $T$. truncatus stored in collections as a source of mitochondrial DNA for population genetics and taxonomic studies.

\section{MATERIALS AND METHODS}

\section{Sampling}

Dentin samples were obtained from teeth of $T$. truncatus specimens collected in South Brazil, which were stored dry in the Marine Mammal Laboratory of the Universidade Federal do Rio Grande - FURG (Table 1). Preparation of material for storage in this collection was done by maceration of the skull in water, followed by cleansing with detergent. Skulls were then whitened with commercial grade sodium hypochloride before incorporating them into the collection.

Table 1 - Tursiops truncatus. Samples used for DNA extraction. Specified date refers to the year the specimen was added to the collection.

\begin{tabular}{l|c|c}
\hline Collection Number & Genre & Date \\
\hline LMM0072 & M & 1978 \\
LMM0078 & - & 1979 \\
LMM0469 & F & 1983 \\
LMM0538 & F & 1983 \\
LMM0690 & - & 1985 \\
LMM0877 & F & 1986 \\
LMM1089 & - & 1987 \\
LMM1188 & M & 1987 \\
LMM1195 & F & 1988 \\
LMM1205 & - & 1988 \\
LMM1310 & M & 1993 \\
LMM1420 & M & 1993 \\
LMM1827 & F & 1995 \\
\hline
\end{tabular}

(M) male; (F) female. 
After or during the cleaning phase, teeth were usually removed from the skull and stored individually in plastic bags. Samples used in this study were from teeth that were used for ageing animals. The ageing process included cutting the teeth in two halves, and while one side was used for ageing, the other was stored in the collection, and was the one used in this study.

\section{Sample Preparation for DNA Extraction}

\section{Decontamination Procedure}

Teeth were first decontaminated following protocols recommended by DeGusta (1994). First, remains of an epoxi adhesive used to maintain the teeth in the right position while cutting, were removed from teeth by using sterilised scalpel and sandpaper. Then, they were submerged in absolute ethanol overnight, and on the next day, they were submerged for $1 \mathrm{~h}$ in $12 \%$ sodium hypochloride. After this process, they were submitted to UV irradiation $(354 \mathrm{~nm})$ for $5 \mathrm{~min}$ on each side.

\section{Grinding Procedure}

After the decontamination procedure, the teeth were grinded with a dentist drill or by hand with a mortar after being frozen with liquid nitrogen. Teeth that had been cut for the ageing process were already broken in the middle, while others were divided on purpose by an ISOMET lowspeed saw. Also, some were kept entire and grinding started from the outside. All instruments used for crushing and grinding were cleaned with sodium hypochloride. The powder obtained by this process was weighed and submitted to the demineralisation procedure.

\section{Demineralisation Procedure}

Demineralisation of dentin powder was done by incubating each sample in $700 \mathrm{uL}$ to $1 \mathrm{ml}$ of EDTA $0.5 \mathrm{M} \mathrm{pH} 8.5$ for $48 \mathrm{~h}$ at room temperature. Afterwards EDTA solution was descarted.

\section{DNA Extraction}

DNA from dentin powder and from positive controls (muscle tissue) were extracted by the Silica-Guanidinium isothiocyanate (GUSCN) method, modified from Boom et al. (1990) and Höss and Pääbo (1993) by Hoelzel (1998). Extraction was initiated with 0.08 to $0.3 \mathrm{~g}$ of dentin powder of each sample, to which was added $1 \mathrm{ml}$ of lisis buffer $(50 \mathrm{mM}$ Tris- $\mathrm{HCl}, \mathrm{pH} 7.0 ; 25 \mathrm{mM}$ EDTA, $\mathrm{pH} \quad 8.0 ; 1.25 \%$ Triton-X-100; $5 \mathrm{M}$ GUSCN) and incubated overnight at room temperature. Then, it was centrifuged at $12,500 \mathrm{x} \mathrm{g}$ for ten minutes at $16^{\circ} \mathrm{C}$. Supernatant was collected and transferred to a new tube, and added $700 \mu \mathrm{L}$ of DNA binding solution (50mM Tris- $\mathrm{HCl}, \mathrm{pH} 7.0$; 25mM EDTA, pH 8.0; 5M GUSCN; $1 \%$ (w/v) of silica slurry). The mix was maintained for two hours in a rotating wheel. Afterwards, it was centrifuged for $2 \mathrm{~min}$ at the same speed, and then the supernatant was eliminated. The silica pellet with the DNA was washed three times with $70 \%$ ethanol, dried at $56^{\circ} \mathrm{C}$ and re-suspended with $80 \mu \mathrm{L}$ of TE.

\section{DNA amplification by PCR}

\section{S rRNA gene}

The amplification of 16 subunit of the mitochondrial rRNA gene was performed by PCR (Polymerase Chain Reaction) using universal primers: AR 5'-CGCCTGTTTATCAAAAACAT3' and BR 5'-CCGGTCTGAACTCAGATCAC GT-3' described by Palumbi et al. (1991), which amplify a region close to 527 bp in invertebrates. Many universal primers for mitochondrial genes have provem to be useful for both vertebrates and invertebrates taxa, therefore these primers were tested for Tursiops. The amplification was done in a reaction of $25 \mu \mathrm{l}$ of final volume, using $5 \mu \mathrm{L}$ of extracted DNA, 1x PCR buffer, $3 \mathrm{mM} \mathrm{MgCl}_{2}$, $0.4 \mathrm{mM}$ of dNTPs, $4 \mu \mathrm{M}$ of each primer, $0.1 \%$ of triton-X-100, and $1 \mathrm{U}$ Taq polymerase. The thermocycler was programmed for the following steps: initial denaturing step at $95^{\circ} \mathrm{C}$ for $3 \mathrm{~min} ; 30$ cycles of $94^{\circ} \mathrm{C}$ for $20 \mathrm{~s}$ (denaturing), $51^{\circ} \mathrm{C}$ for $20 \mathrm{~s}$ (annealing) and $72^{\circ} \mathrm{C}$ for $45 \mathrm{~s}$ (extension); and a final extension step of $5 \mathrm{~min}$ at $72^{\circ} \mathrm{C}$.

\section{BDR region of Cytochrome-b gene}

A second locus was tested, an inside fragment of $59 \mathrm{bp}$ (without primers, 123 bp counting primers sequence) of the so called BDR region, which corresponds to a longer sequence of the Cytochrome-b gene previously studied by Barlett and Davidson (1991) from raw data of tunas. Unseld et al. (1995) designed primers for the inside shorter fragment of the BDR region in order to obtain results coming from highly degraded DNA.

In order to amplify this region was used also a 
final volume reaction of $25 \mu \mathrm{L}$ containing $1 \mathrm{x}$ PCR buffer, $0.2 \mathrm{mM}$ of each dNTPs, $1 \mu \mathrm{M}$ of each primer, $2 \mathrm{mM} \mathrm{MgCl}_{2}, 1 \mathrm{U}$ of Taq polymerase and $5 \mu \mathrm{L}$ of extracted DNA. The primers used were described by Unseld et al. (1995) for a conservative region of vertebrate mitochondrial DNA Cytochrome-b gene of 123 bp: CITBF59 5'AAACTGCAGCCCCTCAGAATGATATTTGTC CTCA-3' and CITBR59 5'-GCTGGTACCTCTA CAAAGAAACATGAAACA-3'. Amplifications were done by the following steps in a thermocycler: $94^{\circ} \mathrm{C}$ for $5 \mathrm{~min}$ as an initial denaturing step; 35 cycles, each including a denaturing step at $94^{\circ} \mathrm{C}$ for $40 \mathrm{~s}$, annealing step at $50^{\circ} \mathrm{C}$ for $80 \mathrm{~s}$ and an extension step at $72^{\circ} \mathrm{C}$ for 80 $\mathrm{s}$; an extra $7 \mathrm{~min}$ of extension was added. PCR products were separated by size in horizontal electrophoresis using 1.5\% agarose gel and were visualised with Ethidium Bromide $(0.5 \mu \mathrm{g} / \mathrm{ml})$ under UV exposition. A fragment size and concentration standard, Low DNA Mass Ladder (Invitrogen), was used for comparison with the obtained products. For the BDR region, a second positive control was used, corresponding to another vertebrate species, Thunnus alalunga (Bonnaterre, 1788).

The initial quantity of dentin powder (in g) used for DNA extraction was related to the concentration of amplified DNA $(\mathrm{ng} / \mu \mathrm{L})$ through a regression analysis, model I (Sokal and Rohlf, 1995) using the Statistica for Windows XP, v. 6, 2001, Statsoft Inc.

\section{Analysis of SSCP}

After the amplification of the BDR region, PCR products were analysed by SSCP (Single Stranded Conformational Polymorphism) including amplicons obtained from DNA extracted from muscle from three different individuals of $T$. truncatus, from Thunnus alalunga plus amplicons from human DNA of two individuals involved in the analyses. The aim at this stage was to rule out the possibility of contamination. This analysis was done by an electrophoresis of PCR products in a vertical $6 \%$ polyacrilamide natural gel (Crosslink $75: 1)$ at 15 Watts for $5 \mathrm{~h}$. Denaturation during 5 $\min$ at $95^{\circ} \mathrm{C}$ in formamide loading buffer preceeded electrophoresis. SSCP patterns were visualised by Silver Staining following Hoelzel (1998).

\section{RESULTS AND DISCUSSION}

The present work showed that teeth samples of dolphins preserved in collections were a good source of mitochondrial DNA for population genetics and taxonomic studies. The positive results in obtaining DNA showed that the pretreatment of samples chosen for decontamination from exogenous sources was efficient and did not damage totally the DNA, leaving enough DNA for the amplification of the region of interest. Rosenbaum et al. (1997) did not succeed in obtaining DNA from Baleen plates after soaking them overnight in absolute ethanol, as was done in the present work. They were able to obtain DNA only when submitted them to a surface cleaning with this component. In the case of teeth the DNA is localised internally surrounding the pulp cavity, therefore, it may be less exposed to the ethanol. The demineralization process was necessary because it was expected that mineral compounds were likely to inibit the PCR, which were also responsible for the higher preservation of DNA at this regions. Kiesslich et al. (2002) described an efficient and quick method of DNA purification by the use of dialysis using nitrocellulose membranes. The silica-GUSCN protocol for DNA extraction was efficient for the present purpose of extracting DNA from grained teeth, showing that it was a good protocol for difficult templates as was stated previously by Hoelzel (1998). More recently, other authors have used other extraction protocols for preserved part of specimens from collections, such as Proteinase-k for lisis, Phenol/Chloroform for purification, and absolute ethanol for precipitation (Rosenbaum et al., 1997; Sweet and Hildebrand, 1998) and alternatively using nitrocelulosemediated dialysis for purification (Kiesslich et al., 2002). The sillica-GUSCN protocole has the advantage of providing highly pure DNA, eliminating known and unknown PCR inibitors (Höss and Pääbo, 1993; Yang, 1997).

The primers used for amplifying the 16S rRNA mitochondrial gene described by Palumbi et al. (1991) were not useful for obtaining part of this gene in T. truncatus. Therefore, it seemed that they were not useful for vertebrates. These primers have proven to be very useful in a variety of invertebrates (Palumbi et al., 1991; Rawson and Hilbish, 1995; pers. obs.). In the case of the BDR region of the Cytochrome-b gene, the primers tested, described by Unseld et al. (1995) for a very conservative region of vertebrate species, were 
useful for amplifying this gene in T. truncatus. The fragment obtained for this species was close

to $123 \mathrm{bp}$, the size observed for tunnids (Fig.1).

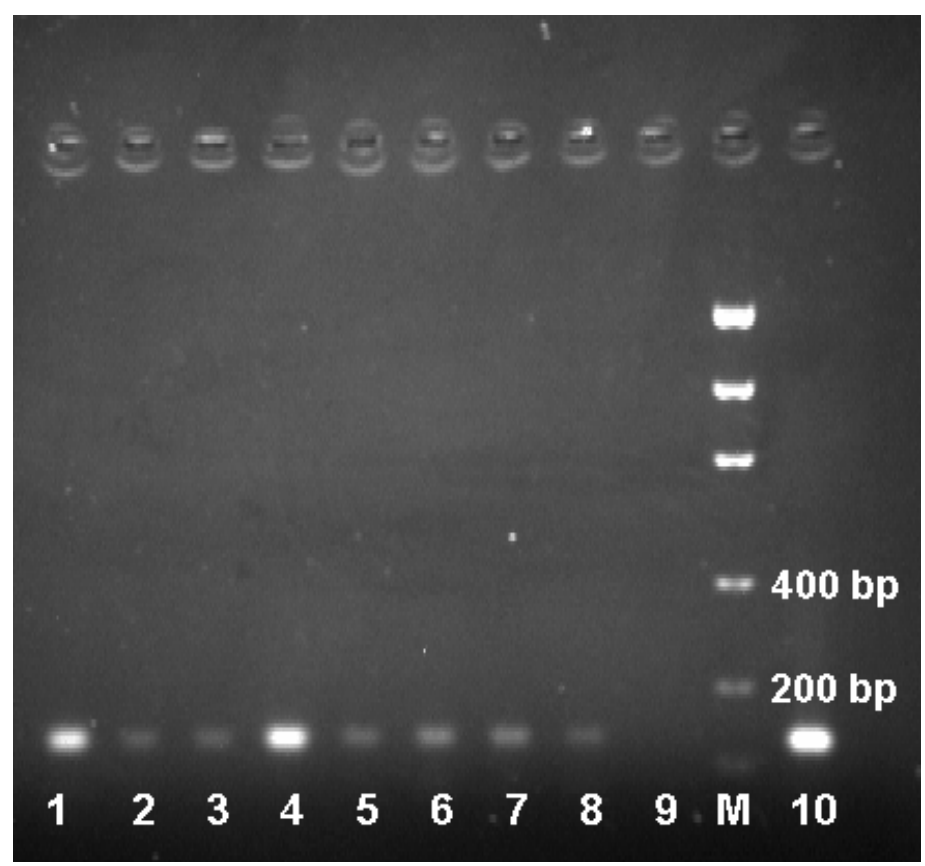

Figure 1 - Amplified fragment of the BDR region of the mtDNA Cytochrome-b gene obtained from dentin powder of preserved teeth: (1-3, 5-8) dentin of T. truncatus; (4) muscle tissue of T. truncatus, positive control; (9) water as a negative control; (M) Low DNA Mass Ladder (Invitrogen); and (10) muscle tissue of tunnid species, positive control.

The yield of PCR product tended to increase with higher quantities of dentin powder used for DNA extraction (see linear regression in Fig. 2) and no negative results were found when quantities over $110 \mathrm{mg}$ were used. Although the correlation was very low $(r=0.492)$ between the quantity of dentin powder used for DNA extraction and the concentration in $\mathrm{ng} / \mu \mathrm{l}$ of the amplified fragment of the BDR region of the Cytochrome-b gene $(y=$ $0.464+22.127 x)$, the regression was significant $(p=0.045)$ and when adjusting to an intercept of zero (no DNA implies no amplified product) the correlation increased to $\mathrm{r}=0.816$ turning it highly significant $(\mathrm{p}<0.0001)$.

Although enough quantity of DNA was extracted from individual teeth for PCR, it yielded only few nanogrames after amplification. Sweet and Hildebrand (1998) recovered quantities of extracted DNA up to $97.5 \mu \mathrm{g}$ from fresh human molars. Of course this high yield was achieved only from fresh tissue of the pulp cavity of recently extracted teeth. After death, cells around the pulp cavity suffered chemical degradation due to hydrolitic processes (Lindahl, 1993) and oxydative damage (Höss et al., 1996), which led to chain-breaking vulnerability, as well as physical fragmentation due to enzimatic activity by bacteria that digested the DNA (Yang, 1997). It has proven that DNA decay is not linear and shows an initial rapid decay shortly after death, showing afterwards a "plateau effect" of largely reduced damage (Yang, 1997). Therefore, the immediate post-mortem period is critical. Collection parts that were preserved in dry showed lower levels of DNA damage. Hard parts of specimens, such as teeth and bones showed better preserved DNA, which was attributed to the interaction with mineral grains (Keil et al., 1994), with hydroxypatite (Tuross, 1994), and the presence of chemicals that inhibited the action of enzymes that otherwise would degrade the DNA, such as tocopherols and flavonoids (Eglinton and Logan, 1991; Yang, 1997).

Analysis of SSCP allowed ruling out any possible contamination with human and tunnid DNAs, because their SSCP patterns were different from those of Tursiops (Figs. 3 and 4). Polymorphism was detected for the BDR region of Cytochrome-b 
within T. truncatus, where dentin samples showed a unique pattern, while muscle positive controls showed other distinct ones (Fig. 3). Tursiops samples were collected from different geographical regions, suggesting that this polymorphism might be associated to geographical distribution.

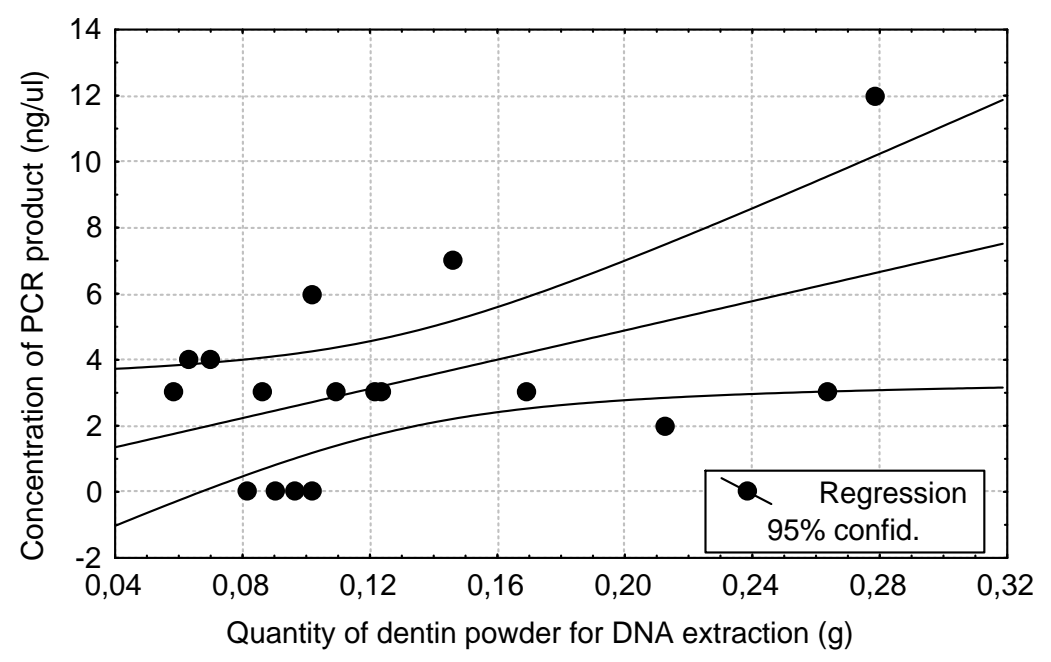

Figure 2 - Tursiops truncatus. Regression analysis for the relationship between the quantity of dentin powder used for DNA extraction and the concentration of the amplicon of the BDR region of Cytochrome-b obtained by PCR.

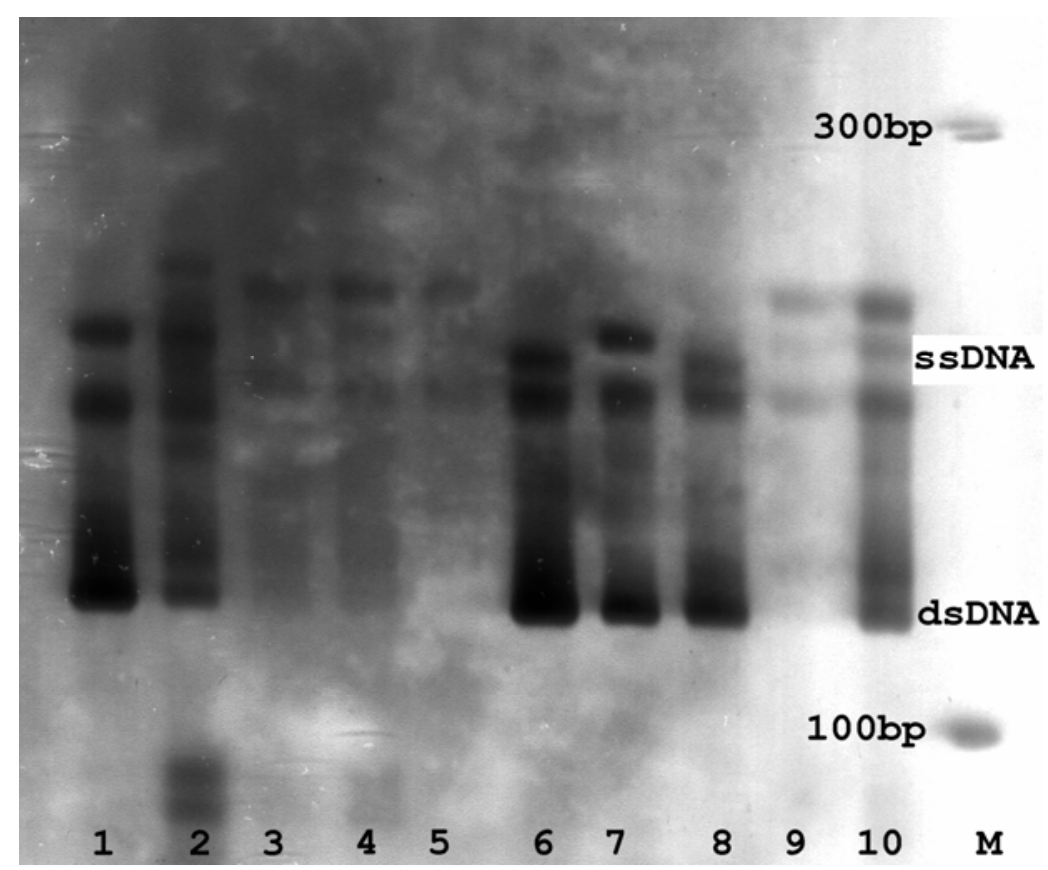

Figure 3 - Patterns of SSCP for the BDR region of Cytochrome-b in humans (1-2) and from dentin (3-5,9-10) and muscle (6-8) of Tursiops truncatus; (M) molecular marker of $100 \mathrm{bp}$. 


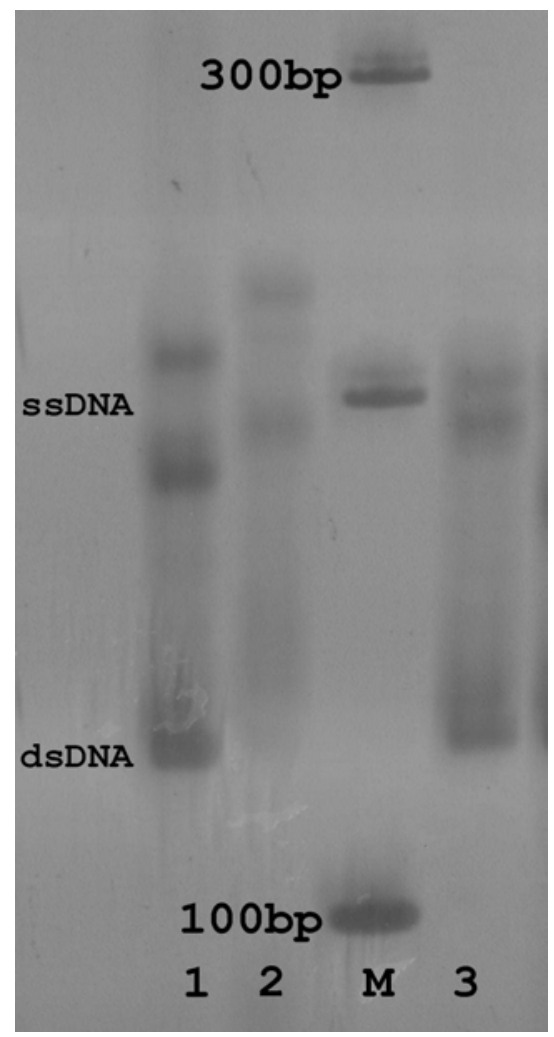

Figure 4 - Patterns of SSCP for the BDR region of Cytochrome-b from Tunnus alalunga (1); from dentin (2) and muscle (3) of Tursiops truncatus; (M) molecular marker of $100 \mathrm{bp}$.

In conclusion, the present work confirmed the possibility of using dentin powder as a source of DNA for bottlenose dolphin population genetics and taxonomic studies through mtDNA analysis.

\section{ACKNOWLEDGEMENTS}

We thank to Dr. M. Cristina Pinedo and to the working group of the Marine Mammals Laboratory of the Fundação Universidade do Rio Grande, Brazil. M.J. de Luca was supported by a scientific initiation grant from PROBic/UNIVALI.

\section{RESUMO}

Vinte e quatro amostras de material dentário de Tursiops truncatus oriundas da coleção do Laboratório de Mamíferos Marinhos (FURG-RS) foram avaliadas para determinar seu potencial como fonte de DNA para estudos genético- populacionais e sistemáticos. Todos os dentes foram submetidos a processos de desinfecção, trituração e desmineralização. A dentina obtida foi pesada previamente à extração de DNA, a qual foi avaliada através da amplificação de dois genes mitocondriais, através da técnica de PCR (Reação em Cadeia da Polimerase), utilizando oligonucleotídeos iniciadores universais. Obtevese sucesso apenas na amplificação do gene Citocromo-b. Destes produtos obtiveram-se concentrações de 3-12 $\mathrm{ng} / \mu \mathrm{l}$ para o material dentário, observando-se uma relação linear positiva com a quantidade em gramas utilizada na extração de DNA. Com o objetivo de eliminar a possibilidade de contaminação foi realizada uma análise SSCP (Polimorfismo Conformacional de Fita Simples) incluindo os controles positivos e amostras de pessoas envolvidas nas análises. Os padrões SSCP de T. truncatus obtidos diferiram das outras amostras, observando-se polimorfismo na região para os exemplares de $T$. truncatus analisados. Concluiu-se que é possível obter DNA mitocondrial para estudos genético-populacionais 
e taxonômicos a partir de material dentário de golfinhos.

\section{REFERENCES}

Amos, W. (1997), Marine mammal tissue sample collection and preservation for genetics analyses. In: Molecular Genetics of Marine Mammals, eds. A. E. Dizon, S. J. Chivers and W. F. Perrin. The Society for Marine Mammalogy, Lawrence, pp. 107-113.

Barlett, S. E. and Davidson, W. S. (1991), Identification of Thunnus Tuna species by the Polymerase Chain Reaction and Direct Sequence Analysis of their mitochondrial Cytochrome b genes. Canadian Journal of Fisheries and Aquatic Science, 48, 309-317.

Barreto, A. S. (2000), Variação craniana e genética de Tursiops truncatus (Delphinidae, Cetacea) na costa Atlântica da América do Sul. PhD Thesis, Fundação Universidade do Rio Grande, Rio Grande, Brazil.

Barreto, A. S. (2004), Tursiops in Atlantic South America: Is Tursiops gephyreus a valid species? Paper presented at the Symposium on Cetacean Systematics, 28-29 April, La Jolla, USA.

Boom, R.; Sol, C. J. A.; Salimans, M. M. M; Jansem, P. M. E.; Wertheim-van Dillen, P. M. E. and van der Noordaa, J. (1990), Rapid and simple method for purification of nucleic acids. Journal of Clinical Microbiology, 28, 495-503.

DeGusta, D. (1994), Dentin as a source of ancient DNA. Ancient DNA Newsletters, 2, 13.

Eglinton, E. and Logan, G. A. (1991), Molecular preservation. Philosophical transactions of the Royal Society of London B, 333, 315-326.

Hoelzel, A. R. (1998), Molecular genetic Analysis of Populations. A Practical Approach. $2^{\text {nd }}$. Ed., Oxford University Press.

Höss, M. and Pääbo, S. (1993), DNA extraction from Pleistocene bones by a silica-based purification method. Nucleic Acids Research, 21, 3913-3914.

Höss, M.; Jaruga, P.; Zastawny, T. H.; Dizdaroglu, M. and Pääbo, S. (1996), DNA damage and DNA sequence retrieval from ancient tissues. Nucleic acid Research, 24, 1304-1307.

Keil, R. G.; Montlucon, D. B.; Prahl, F. G. and Hedges, J. I. (1994), Sortive prreservation of labile organic matter in marine sediments. Nature, 370, 549-552.

Kiesslich, J.; Radacher, M.; Neuhuber, F.; Meyer, H. J. and Zeller, K. W. (2002), On the use of nitrocellulose membranes for dialysis-mediated purification of ancient DNA from human bone and teeth extracts. Ancient Biomolecules, 4, 79-87.

Leatherwood, S. and Reeves, R. R. (1983), The Sierra Club Handbook of Whales and Dolphins. Sierra Club Books, San Francisco.

Lindahl, T. (1993), Instability and decay of the primary structure of DNA. Nature, 362, 709-715.
Miranda, C. M. and Barreto, A. S. (2002), Ocorrência de duas formas do gênero Tursiops no litoral de Santa Catarina e norte do Rio Grande do Sul, Brasil. Paper presented at the $10^{\mathrm{a}}$ Reunión de Trabajo de Especialistas en Mamíferos Acuáticos de América Del Sur, Valdívia, Chile.

Palumbi, S. R.; Martin, A. P.; Romano, S.; Mcmilan, W. O.; Stice, L. and Grabowski, G. (1991), The simple fool's guide to PCR. University of Hawaii.

Pinedo, M. C.; Rosas, F. C. W. and Marmonel, M. (1992), Cetáceos e Pinípedes do Brasil. IINEP/FUA.

Powell, J. A. (2002), National Audubon Society Guide to Marine Mammals of the World. Alfred A. Knopf, New York, USA.

Rawson, P. D. and Hilbish, T. J. (1995), Evolutonary relationships among the male and female mitochondrial DNA lineages in the Mytilus edulis species complex. Molecular Biology and Evolution, 12, 893-901.

Reeves, R. R.; Stewart, B. S.; Clapham, P. J. and Reeves, R. R., Perrin, W. F., Taylor, B. L., Baker, C. S. and Mesnick, S. L. (2004), Report of the Workshop on Shortcomings of Cetacean Taxonomy in Relation to Needs of Conservation and Management. NOAA Technical Memorandum NOAA-NMFS-SWFSC363. 94 pp.

Rice, D. W. (1998), Marine Mammals of the World. Systematics and Distribution. Society for Marine Mammalogy, Special Publication 4.

Rosenbaum, H. C.; Egan, M. G.; Clapham, P. J.; Brownell, R. L. and Desalle, R. (1997), An effective methods for isolating DNA from historical specimens of baleen. Molecular Ecology, 6, 677-681.

Secchi E. R.; Wang J. Y.; Murray, B. W.; RachaCampos, C. C. and White, B. N. (1998), Population differentiation in the fransiscana (Pontoporia blainvillei) from two geographic locations in Brazil as determined from mitochondrial DNA control region sequences. Canadian Journal of Zoology, 76, 1-6.

Sokal, R. R. and Rohlf, F. J. (1995), Biometry. W.H. Freeman and Company, N.Y., 887 pp.

Sweet, D. and Hildebrand, D. (1998), Recovery of DNA from human teeth by cryogenic grinding. Journal of Forensic Science, 43, 1199-1202.

Tuross, N. (1994), The biochemistry of ancient DNA in bone. Experientia, 50, 530-535.

Unseld, M.; Beyermann, B.; Brandt, P. and Hiesel, R. (1995), Identification of the species of origin of highly processed meat products by mitocondrial DNA sequences. PCR Methods and Applications, 4, 241-243.

Wang, J. Y.; Chou, L. S. and White, B. N. (1999a), Mitochondrial DNA analysis of sympatric morphotypes of bottlenose dolphins (genus: Tursiops) in Chinese waters. Molecular Ecology, 8, 1603-1612. 
Wang, J. Y.; Chou, L. S. and White, B. N. (1999b) Osteological differences between two sympatric forms of bottlenose dolphins (genus: Tursiops) in Chinese waters. Journal of Zoology, 252, 147-162.

Yang, H. (1997), Ancient DNA from Pleistocene Fossils: Preservation, recovery, and utility of ancient genetic information for quaternary research. Quaternary Science Reviews, 16, 1145-1161.

Received: March 15, 2005;

Revised: August 08, 2005; Accepted: October 09, 2006. 


\section{PÁGINA}

EM

BRANCO 